\title{
Anglicisms in Spanish in Puerto Rico: An Educational-Conversational Approach
}

\author{
Mylord Reyes Tosta ${ }^{a}$
}

\author{
Received: 23 April 2019 Accepted: 30 July 2019
}

\begin{abstract}
In this qualitative ethnographic study, 80 anglicisms were identified in the rapid-informal speech of Puerto Ricans. For the collection of data, various Puerto Rican television programs and YouTube videos were used. The data were then organized according to their orthographic representation, anglicism classification, phonetic representation, English original word, and Spanish equivalent. It is considered that English has considerable influence in the Spanish of the Island because there is a federation with the United States of America. Therefore, it becomes a very special linguistic phenomenon that identifies Puerto Rican culture. And that it has interesting repercussions on linguistic education.
\end{abstract}

Key-words: Anglicism, Lexicon, Phonetic Representation, Language Contact, Linguistic Education.

\section{Introduction}

Language is a cultural component of the utmost importance, and it is part of human nature for the development and well-being of individuals and nations. According to Escobar and Potowski (2015), approximately 400 million people in the world speak Spanish, and Spanish is second only to Chinese in numbers of native speakers. Puerto Rico has about 3.4 million inhabitants, and its official language is Spanish (Instituto de Estadísticas de Puerto Rico, 2016). However, in this country, as in all countries with their respective languages, there is a linguistic variation according to the situation in which the speakers are communicating, the topic of conversation, and the type of speech (Medina-Rivera, 1999). In addition, syntactic frequency of anglicisms due to the influence of the English of the United States is notable (Rodríguez, 2002). Additional changes exposed by other researchers include

\footnotetext{
a Wayne State University (United States). Correspondence: Mylord Reyes Tosta, 906 West Warren 487 Manoogian Detroit, MI 48202, United States. gq1801@wayne.edu.
} 
the presence of "estar" in structures that were previously limited to "ser" (Negrón, 2013), as well as many syntactic innovations in complex superlative constructions in Spanish on the Island (Olivero, 2012). Given the constant variations that this language experiences, it is necessary to empirically determine the extent and types of influence that the English of the United States has had on the Spanish of Puerto Rico for a better understanding of the communication processes between this country and the rest of the world.

The objective of this study was to determine the lexical influence of United States English on Spanish in Puerto Rico using various television programs and YouTube videos. To conduct it, the following question was used: What anglicisms in Spanish in Puerto Rico can be identified in television programs and YouTube videos? For the reader to have a better understanding, the following variables are defined:

Anglicism. La Real Academia Española (2017) defines anglicism as a word or turn of the English language used in another language. In this study, this variable implies the adaptation, lending, modification (or combination thereof), at the lexical level of English found in the rapid-informal Spanish spoken by Puerto Ricans.

Lexicon. It is a collection of words from a language that belongs to a specific field, area, or region (Cordero-Monge, 2007). The anglicisms found in this study are part of the vocabulary (lexicon) of the speakers of Puerto Rico.

Phonetics. It is the part of the grammar that studies the mechanisms of production, transmission, and perception of the sound signals that constitute speech (Real Academia Española, 2017). Anglicisms appear phonetically in the rapid-informal speech of Puerto Ricans living on the Island.

\section{Theoretical Framework}

The sociolinguistic theory of language presented by J. K. Chambers (2009) was used. Linguistic phenomena and changes influenced by social and cultural factors are explained. The starting point is that language is a social or cultural product and should be understood as such. Therefore, this theory relies on linguistic variation and the social significance. The first aspect is to recognize the uses of language. Among these are: informational use (descriptions, propositions, information), expressive use (feelings, attitudes, emotions), and directive use (orders, requests).

A second component in this theory is to explain linguistic variation. Every language experiences changes over time. Speakers use different linguistic elements to express new things or ideas or to express familiar things or ideas in new ways. Linguistic variation is the substitution of one linguistic element for another without affecting its referential meaning. That is, altering two or more expressions of the same element, when there is no alteration or 
change of a semantic nature and the alteration is conditioned by linguistic and social factors. Four types of variation are presented: syntactic, phoneticphonological, lexical, and discursive (Chambers, 2009).

Linguistic inferences fall into five categories: personal, stylistic, social, and sociocultural. The personal ones are those of the speaker when he/she communicates; for example, the tone of voice, ceceo, the use of muletillas, and the fluent or hesitant speech. Stylistic inferences occur depending on whether the environment is formal or informal (family). In an informal environment, the discourse is usually fast and casual vocabulary is used. On the other hand, sex, age, ethnicity, and social class with its sub elements (education, occupation, income, and type of housing), are social variables that cause changes in spoken and written language. The higher the profile of these sub elements, the more formal the writing and the way ideas are expressed. Among the socio-cultural characteristics that influence language are religion, traditions, and customs. The norms imposed or voluntarily complied with by these variables cause changes in the discourse (Chambers, 2009).

An example of the linguistic variation mentioned earlier in this theory is the Anglicisms of Spanish in Puerto Rico. This phenomenon is a product of what is called: languages in contact. According to Wheeler (2015), this occurs when one community interacts with another, with effects of that interaction on their respective linguistic behaviors. An extreme effect would be the replacement of language for one or both communities; a moderate effect would include language adaptations, language loans, and combinations of those.

Wheeler (2015) presented four dimensions to consider in the language contact process:

- The nature of the communities involved. This involves determining the quantity and size of communities, social structures, and power.

- The nature of the language being studied. It is necessary to study the traditional sub fields of languages: phonetics, morphology, lexicon, syntax, semantics, and pragmatics. Also, it is important to know the homogeneity and similarity among languages.

- The way the contact occurs. Knowledge of the geography of places, the duration of contact, the history of languages, and the intensity of interactions are very important in the analysis.

- The type of study. Case studies are typically descriptive or explanatory.

In this study, as a product of language contact (Spanish and English), 80 anglicisms that Puerto Ricans currently use were identified. These are classified into adapted anglicisms, crude, hybrid, and anglicized neologisms. In addition, the phonetic representation, the original word in English, and the equivalent in Spanish are presented. This additional information allows the 
reader to have a clearer picture of the phenomenon to draw his/her own conclusions.

\section{Historical Context of English in Puerto Rico}

After the war between Americans and Spaniards in 1898, Spain ceded Puerto Rico to the United States of America. This event allowed Puerto Rico to be seen as a colony of the American nation. In 1900, Congress passed the Foraker Law during the presidency of William McKinley. This law allowed Puerto Rico to recover its civil government, but it continued being a colony. Later, under the presidency of Woodrow Wilson, the Jones Act was signed in 1917, granting American citizenship to those born on the Island (Regis, 1998).

In 1952, Puerto Rico was established and declared as a regime called commonwealth, better known in Spanish as estado libre asociado. According to the definition of this term, both countries voluntarily partner to share common goals and interests. David Rezvani stated that many believe that nothing has changed and that Puerto Rico remains a colony under the absolute power of the United States Congress. However, he explained, that this country is neither merely a colony nor are its powers formally safeguarded by the pact created in 1952; rather, it is a conventionally entrenched federation (Rezvani, 2007).

From the association of Puerto Rico with the United States, along with political and economic changes came cultural changes. For more than a century there have been different laws, opinions, activities, and debates related to Spanish and English as contact languages in Puerto Rico. In 1902, the Official Languages Law was created so that both Spanish and English were used interchangeably on the Island. Although this law provided for both languages to have the same weight, English was established as the primary language of instruction in the public educational system of Puerto Rico (Shenk, 2012). By 1940, arguments in favor of Spanish as a means of instruction gained importance in opposition to American English. As a consequence, in 1991, the legislature passed Law No. 4, under which Spanish was established as the only official language, thus repealing the 1902 law. However, in 1993, Law No. 1 formalized both languages again.

After the approval of Law No.1, an avalanche of debates and efforts arose to restore Spanish as the only official language and leave English in a secondary position. Citizens resisted both the loss of Spanish and the presence of English (Shenk, 2012). For a long time in the twentieth century, the issue of Spanish versus English was present in the political and academic discourse to defend the Spanish language as a symbol of Puerto Rican cultural identity. However, the reality that Puerto Rico lives is that $95 \%$ of its inhabitants speak Spanish and 85\% do not speak English very well (U.S. Census Bureau, 2011). 
These data show the preference and importance given to Spanish and keeping English as a second language.

Regarding the methodology of this study, a qualitative ethnographic realistic approach was used. This design is ideal for an objective account of cultural phenomenon, in this case, language (Creswell, 2013). This methodology began to be used in the 1960s and is widely used in social anthropology. It is characterized by "participant observation and the use of reflexivity" (Apud, 2013). This method informs about rules, actions, and meanings of the subjects studied that are obtained in a realistic environment of the events that occurred.

The data was obtained from Puerto Rican television and YouTube videos of the population living on the Island. The summative content analysis technique was used to analyze the data. According to Hsieh and Shannon (2005), this "implies the counting and comparisons of the keywords followed by the interpretation of the underlying context." This process begins with the identification and quantification of certain words or phrases with the purpose of understanding contextual use. Next, the interpretation of the content is made to discover outstanding meanings with the identification of topics, similarities, and differences in the study material.

Table 1 presents the results at the lexical level of the influence of American English on Spanish in Puerto Rico after listening to and watching various television programs on the Island and YouTube videos during the months of September, October, and November 2017. The television programs that were selected to obtain the data were informative and entertaining. YouTube videos in which the speech is Puerto Rican Spanish were randomly selected. A general description of the analyzed samples is included in Table 2. The data is organized into four sections: 1) spelling and classification of anglicisms, 2) the phonetic representation of the corresponding rapid speech, 3) the original words in English and 4) their equivalents in Spanish. Anglicisms classified as original, adapted, hybrid, and angled neologisms appear in the first column of the table. The original maintain their original form in English, but with the phonetic-phonological expression of the speakers of Puerto Rico. The adapted ones keep the English root with a Spanish ending or some combination of both. In the hybrids, elements of the two languages are combined, and the angled neologisms give a new meaning or new turn to the word.

\begin{tabular}{|l|l|l|l|}
\hline $\begin{array}{c}\text { Spelling and } \\
\text { classification of } \\
\text { anglicism }\end{array}$ & $\begin{array}{c}\text { Phonetic } \\
\text { representation of rapid } \\
\text { speech }\end{array}$ & $\begin{array}{c}\text { Original in } \\
\text { English }\end{array}$ & $\begin{array}{c}\text { Equivalent in } \\
\text { Spanish }\end{array}$ \\
\hline $\begin{array}{l}\text { accesar } \\
\text { (anglicismo } \\
\text { adaptado 1) }\end{array}$ & [ak.se. 'sar] & to access & acceder \\
\hline
\end{tabular}


Mylord Reyes Tosta. International Journal of Educational Excellence (2019) Vol. 5, No. 2, 15-

28. ISSN 2373-5929.

DOI: $10.18562 /$ IJEE.046

\begin{tabular}{|c|c|c|c|}
\hline $\begin{array}{l}\text { rufo } \\
\text { (anglicismo } \\
\text { adaptado 2) }\end{array}$ & ['ru.fo] & roof & techo \\
\hline $\begin{array}{l}\text { printear } \\
\text { (anglicismo } \\
\text { adaptado 3) }\end{array}$ & [prin. 'tjar] & to print & imprimir \\
\hline $\begin{array}{l}\text { carpeta } \\
\text { (anglicismo } \\
\text { adaptado 4) }\end{array}$ & [kar. 'pe.ta] & carpet & alfombra \\
\hline $\begin{array}{l}\text { compulsorio } \\
\text { (anglicismo } \\
\text { adaptado 5) }\end{array}$ & [com.pul.'so.rjo] & compulsory & obligatorio \\
\hline $\begin{array}{l}\text { cachar } \\
\text { (anglicismo } \\
\text { adaptado 6) }\end{array}$ & [ka.'tfar] & to catch & coger, atrapar \\
\hline $\begin{array}{l}\text { suinguiar } \\
\text { (anglicismo } \\
\text { adaptado 7) }\end{array}$ & [swin. 'gjar] & to swing & girar \\
\hline $\begin{array}{l}\text { data } \\
\text { (anglicismo crudo } \\
\text { 1) }\end{array}$ & ['da.ta] & data & datos \\
\hline $\begin{array}{l}\text { yarda } \\
\text { (anglicismo } \\
\text { adaptado 8) }\end{array}$ & ['jar.ða] & yard & patio \\
\hline $\begin{array}{l}\text { fon } \\
\text { (anglicismo crudo } \\
\text { 2) }\end{array}$ & [fon] & foam & espuma \\
\hline $\begin{array}{l}\text { liqueo } \\
\text { (anglicismo } \\
\text { adaptado 9) }\end{array}$ & [li. 'ke.o] & to leak & goteo \\
\hline $\begin{array}{l}\text { disectar } \\
\text { (anglicismo } \\
\text { adaptado 10) }\end{array}$ & [di.sck.'tar] & to dissect & disecar \\
\hline $\begin{array}{l}\text { eirbag } \\
\text { (anglicismo crudo } \\
3 \text { ) }\end{array}$ & ['ejr.ßay] & air bag & bolsa de aire \\
\hline $\begin{array}{l}\text { indentar } \\
\text { (anglicismo } \\
\text { adaptado 11) }\end{array}$ & [in.den. 'tar] & to indent & sangrar \\
\hline $\begin{array}{l}\text { badtripeao } \\
\text { (anglicismo } \\
\text { adaptado 12) }\end{array}$ & [bað.tri.'pjaw] & bad trip & experiencia negativa \\
\hline $\begin{array}{l}\text { fatfri } \\
\text { (anglicismo crudo } \\
\text { 4) }\end{array}$ & [fat. 'fri] & fat free & libre de grasa \\
\hline $\begin{array}{l}\text { magnificacion } \\
\text { (anglicismo } \\
\text { adaptado 13) }\end{array}$ & [may.ni.fi.ka.'sjon] & magnification & aumento \\
\hline $\begin{array}{l}\text { recreacional } \\
\text { (anglicismo } \\
\text { adaptado 14) }\end{array}$ & [re.krja.sjo.'nal] & recreational & recreativo \\
\hline similaridad & [si.mi.la.ri.'ðað] & similarity & semejanza \\
\hline
\end{tabular}


Mylord Reyes Tosta. International Journal of Educational Excellence (2019) Vol. 5, No. 2, 15-

28. ISSN 2373-5929.

DOI: $10.18562 /$ IJEE.046

\begin{tabular}{|c|c|c|c|c|}
\hline $\begin{array}{l}\text { (anglicismo } \\
\text { adaptado 15) }\end{array}$ & & & & \\
\hline $\begin{array}{l}\text { sucrosa } \\
\text { (anglicismo } \\
\text { adaptado 16) }\end{array}$ & & [su. 'kro.sa] & sucrose & sacarosa \\
\hline $\begin{array}{l}\text { norsa } \\
\text { (anglicismo } \\
\text { adaptado 17) }\end{array}$ & & ['nor.sa] & nurse & enfermera \\
\hline $\begin{array}{l}\text { pichar } \\
\text { (anglicismo } \\
\text { adaptado 18) }\end{array}$ & & [pi.'tfar] & pitch & lanzar \\
\hline $\begin{array}{l}\text { so } \\
\text { (anglicismo } \\
5 \text { ) }\end{array}$ & crudo & [so] & so & por lo tanto \\
\hline $\begin{array}{l}\text { jambelgue } \\
\text { (anglicismo } \\
6 \text { ) }\end{array}$ & crudo & [xam.'bcl.ye] & hamburger & hamburguesa \\
\hline $\begin{array}{l}\text { moron } \\
\text { (anglicismo } \\
\text { adaptado 19) }\end{array}$ & & [mo. 'ron] & moron & tonto/a \\
\hline $\begin{array}{l}\text { cel } \\
\text { (anglicismo } \\
\text { adaptado 20) }\end{array}$ & & {$[\mathrm{scl}]$} & celular & teléfono celular \\
\hline $\begin{array}{l}\text { yistro } \\
\text { (anglicismo } \\
\text { adaptado 21) } \\
\end{array}$ & & ['Jis.tro] & g-string & tanga \\
\hline $\begin{array}{l}\text { palkin } \\
\text { (anglicismo } \\
7 \text { ) }\end{array}$ & crudo & ['pal.kin] & parking & estacionamiento \\
\hline $\begin{array}{l}\text { raitru } \\
\text { (anglicismo } \\
8 \text { ) }\end{array}$ & crudo & [raj. 'tru] & right true & verdad, cierto \\
\hline $\begin{array}{l}\text { pichea } \\
\text { (anglicismo } \\
\text { adaptado 22) }\end{array}$ & & [pi.'tyja] & pitch & ignora \\
\hline $\begin{array}{l}\text { niga } \\
\text { (anglicismo } \\
\text { adaptado 23) } \\
\end{array}$ & & ['ni.ya] & nigger & negro \\
\hline $\begin{array}{l}\text { ponchar } \\
\text { (anglicismo } \\
\text { adaptado 24) }\end{array}$ & & [pon. 'tfar] & to punch & $\begin{array}{lll}\text { marcar } & \text { registro de } \\
\text { entrada } & & \end{array}$ \\
\hline $\begin{array}{l}\text { panti } \\
\text { (anglicismo } \\
9 \text { ) }\end{array}$ & crudo & ['pan.ti] & panty & braga, pantaleta \\
\hline $\begin{array}{l}\text { drai } \\
\text { (anglicismo } \\
10)\end{array}$ & $\begin{array}{l}\text { clinin } \\
\text { crudo }\end{array}$ & [draj.'kli.nin] & dry cleaning & lavado en seco \\
\hline $\begin{array}{l}\text { braon } \\
\text { (anglicismo } \\
11)\end{array}$ & crudo & [brawn] & brown & color café \\
\hline $\begin{array}{l}\text { closet } \\
\text { (anglicismo }\end{array}$ & crudo & ['klo.set] & closet & guardarropa \\
\hline
\end{tabular}


Mylord Reyes Tosta. International Journal of Educational Excellence (2019) Vol. 5, No. 2, 15-

28. ISSN 2373-5929.

DOI: 10.18562/IJEE.046

\begin{tabular}{|c|c|c|c|}
\hline 12) & & & \\
\hline $\begin{array}{l}\text { beicon } \\
\text { (anglicismo crudo } \\
13 \text { ) }\end{array}$ & ['bcj.kon] & bacon & tocino \\
\hline $\begin{array}{l}\text { breik } \\
\text { (anglicismo crudo } \\
14)\end{array}$ & [brejk] & break & descanso \\
\hline $\begin{array}{l}\text { par tain } \\
\text { (anglicismo crudo } \\
15)\end{array}$ & [par. 'tajn] & part time & tiempo parcial \\
\hline $\begin{array}{l}\text { brasier } \\
\text { (anglicismo } \\
\text { adaptado 25) }\end{array}$ & [bra.' 'sjer] & bra & sostén \\
\hline $\begin{array}{l}\text { disectar } \\
\text { (anglicismo } \\
\text { adaptado 26) }\end{array}$ & [di.sck.' tar] & to dissect & disecar \\
\hline $\begin{array}{l}\text { caunter } \\
\text { (anglicismo crudo } \\
16)\end{array}$ & ['kawn.tes] & counter & mostrador \\
\hline $\begin{array}{l}\text { taco salad } \\
\text { (anglicismo híbrido } \\
\text { 1) }\end{array}$ & ['ta.ko.'sa.lað] & taco salad & ensalada de taco \\
\hline $\begin{array}{l}\text { lobi } \\
\text { (anglicismo crudo } \\
17 \text { ) }\end{array}$ & ['lo. $\beta \mathrm{i}]$ & lobby & vestíbulo \\
\hline $\begin{array}{l}\text { folder } \\
\text { (anglicismo crudo } \\
18 \text { ) }\end{array}$ & ['fol.der] & folder & carpeta \\
\hline $\begin{array}{l}\text { pai } \\
\text { (anglicismo crudo } \\
19)\end{array}$ & [paj] & pie & pastel \\
\hline $\begin{array}{ll}\text { ful } & \text { cover } \\
\text { (anglicismo } & \text { crudo } \\
20) & \\
\end{array}$ & [ful. 'ko. $\beta \varepsilon r]$ & full cover & cubierta total \\
\hline $\begin{array}{l}\text { set } \\
\text { (anglicismo crudo } \\
21)\end{array}$ & [sct] & set & conjunto \\
\hline $\begin{array}{l}\text { clip } \\
\text { (anglicismo crudo } \\
22)\end{array}$ & [klip] & clip & presilla, broche \\
\hline $\begin{array}{l}\text { matres } \\
\text { (anglicismo } \\
\text { adaptado 27) }\end{array}$ & ['ma.tres] & mattress & colchón \\
\hline $\begin{array}{l}\text { riversa } \\
\text { (anglicismo } \\
\text { adaptado 28) } \\
\end{array}$ & [ri. ' $\beta \varepsilon r . s a]$ & reverse & marcha atrás, reverso \\
\hline $\begin{array}{l}\text { jom ron } \\
\text { (anglicismo crudo } \\
23)\end{array}$ & [xom. 'ron] & home run & carrera \\
\hline $\begin{array}{l}\text { guan guei } \\
\text { (anglicismo crudo } \\
24)\end{array}$ & [gway.gwej] & one way & $\begin{array}{l}\text { una vía, en sentido } \\
\text { único }\end{array}$ \\
\hline
\end{tabular}


Mylord Reyes Tosta. International Journal of Educational Excellence (2019) Vol. 5, No. 2, 15-

28. ISSN 2373-5929.

DOI: $10.18562 /$ IJEE.046

\begin{tabular}{|c|c|c|c|}
\hline $\begin{array}{l}\text { apopai } \\
\text { (anglicismo crudo } \\
25)\end{array}$ & [a.po.'paj] & apple pie & pastel de manzana \\
\hline $\begin{array}{l}\text { ful tain } \\
\text { (anglicismo crudo } \\
26)\end{array}$ & [ful.tajn] & full time & tiempo completo \\
\hline $\begin{array}{l}\text { bacteich } \\
\text { (anglicismo crudo } \\
27)\end{array}$ & ['bak.tejt] & backstage & entre bastidores \\
\hline $\begin{array}{l}\text { carguach } \\
\text { (anglicismo crudo } \\
28)\end{array}$ & [kar. 'ywat]] & car wash & lavado de carro \\
\hline $\begin{array}{l}\text { chatear } \\
\text { (anglicismo } \\
\text { adaptado 29) }\end{array}$ & [ta.'tjar] & chat & platicar, conversar \\
\hline $\begin{array}{l}\text { chisquei } \\
\text { (anglicismo crudo } \\
29)\end{array}$ & [tgis. 'kcj] & cheese cake & pastel de queso \\
\hline $\begin{array}{l}\text { brauni } \\
\text { (anglicismo crudo } \\
30)\end{array}$ & ['braw.ni] & brownie & pastel de chocolate \\
\hline $\begin{array}{l}\text { bisnes } \\
\text { (anglicismo crudo } \\
31)\end{array}$ & ['biz.nes] & business & negocios \\
\hline $\begin{array}{l}\text { over di caunter } \\
\text { (anglicismo crudo } \\
32 \text { ) }\end{array}$ & ['o.ber.ði. 'kawn.ter] & over the counter & $\begin{array}{l}\text { en el mostrador o sin } \\
\text { receta médica }\end{array}$ \\
\hline $\begin{array}{l}\text { cul } \\
\text { (anglicismo crudo } \\
33 \text { ) }\end{array}$ & [kul] & cool & entretenido, atractivo \\
\hline $\begin{array}{l}\text { refil } \\
\text { (anglicismo crudo } \\
34)\end{array}$ & [re.'fil] & refill & volver a llenar \\
\hline $\begin{array}{l}\text { geit } \\
\text { (anglicismo crudo } \\
35 \text { ) }\end{array}$ & [gejt] & gate & puerta \\
\hline $\begin{array}{l}\text { jangear } \\
\text { (neologismo } \\
\text { anglicado 1) }\end{array}$ & [xay.' 'gear] & to hang out & divertirse \\
\hline $\begin{array}{l}\text { los yunais } \\
\text { (anglicismo híbrido } \\
\text { 2) }\end{array}$ & [loz.Ju.'najs] & the United States & los Estados Unidos \\
\hline gringo & ['grin.go] & green go & estadounidense \\
\hline $\begin{array}{l}\text { pai de cheri } \\
\text { (anglicismo híbrido } \\
3 \text { ) }\end{array}$ & [paj.ðe.'tfe.ri] & cherry pie & pastel de cereza \\
\hline $\begin{array}{l}\text { guachiman } \\
\text { (anglicismo crudo } \\
36 \text { ) }\end{array}$ & [gwa.tgi.'man] & watchman & celador \\
\hline $\begin{array}{l}\text { pari } \\
\text { (anglicismo crudo } \\
37 \text { ) }\end{array}$ & ['pa.ri] & party & fiesta \\
\hline
\end{tabular}




\begin{tabular}{|c|c|c|c|}
\hline $\begin{array}{l}\text { luc } \\
\text { (anglicismo crudo } \\
38)\end{array}$ & [luk] & look & apariencia \\
\hline $\begin{array}{l}\text { yim } \\
\text { (anglicismo crudo } \\
39)\end{array}$ & [jim] & gym & gimnasio \\
\hline $\begin{array}{l}\text { topin } \\
\text { (anglicismo crudo } \\
40)\end{array}$ & ['to.pin] & topping & cubierta \\
\hline $\begin{array}{l}\text { rosh } \\
\text { (anglicismo crudo } \\
41)\end{array}$ & [rof] & rush & apuro, prisa \\
\hline $\begin{array}{l}\text { jocdoc } \\
\text { (anglicismo crudo } \\
42 \text { ) }\end{array}$ & [xok.' 'ok] & hot dog & perro caliente \\
\hline $\begin{array}{l}\text { burrito de bif } \\
\text { (anglicismo híbrido } \\
4 \text { ) }\end{array}$ & [bu.'ri.to.ðe.ßif] & beef burrito & $\begin{array}{l}\text { burrito de carne de } \\
\text { res o vaca }\end{array}$ \\
\hline $\begin{array}{l}\text { dámelo plein } \\
\text { (anglicismo híbrido } \\
\text { 5) }\end{array}$ & ['da.me.lo.plejn] & plain & sin otros ingredientes \\
\hline $\begin{array}{l}\text { crispi } \\
\text { (anglicismo } \\
\text { adaptado 30) }\end{array}$ & ['kris.pi] & crisp & crujiente \\
\hline $\begin{array}{l}\text { frape } \\
\text { (anglicismo crudo } \\
43)\end{array}$ & [fra.'pe] & frappe & $\begin{array}{l}\text { bebida refrescante a } \\
\text { base de hielo y fruta }\end{array}$ \\
\hline
\end{tabular}

Table 1. Spelling and classification of anglicism, phonetic representation, original in English, and the equivalent in Spanish.

\begin{tabular}{|l|l|l|l|l|}
\hline & Quantity & Duration & $\begin{array}{l}\text { General } \\
\text { Description of } \\
\text { the Speakers }\end{array}$ & \multicolumn{1}{|c|}{ Type of Speech } \\
\hline $\begin{array}{l}\text { Puerto Rican } \\
\text { television } \\
\text { programs }\end{array}$ & 10 & 16 hours & $\begin{array}{l}\text { Journalists, } \\
\text { reporters, } \\
\text { comedians, } \\
\text { housewives, } \\
\text { office workers, } \\
\text { retirees, and } \\
\text { government } \\
\text { employees (all } \\
\text { adults) }\end{array}$ & $\begin{array}{l}\text { Informational and } \\
\text { entertainment } \\
\text { (interviews, } \\
\text { reports, and } \\
\text { spontaneous } \\
\text { speech) }\end{array}$ \\
\hline $\begin{array}{l}\text { YouTube } \\
\text { videos }\end{array}$ & 20 & $\begin{array}{l}\text { Journalists, } \\
\text { singers, students, } \\
\text { teachers, and } \\
\text { entrepreneurs (all } \\
\text { adults) }\end{array}$ & $\begin{array}{l}\text { Songs, } \\
\text { documentaries, } \\
\text { interviews, } \\
\text { ads, personal } \\
\text { messages, } \\
\text { experiences, and } \\
\text { spontaneous } \\
\text { speech }\end{array}$ \\
\hline
\end{tabular}

Table 2. Samples analyzed: quantity, duration, general description of the speakers and type of speech. 
The anglicisms in the current Spanish of Puerto Rico presented in this study are not the only ones existing on the Island. However, these anglicisms are among the most common that are heard in the rapid-informal speech of this country. As a language varies from one country to another, the Spanish of Puerto Rico differs from the others in terms of the words of Taíno (indigenous) origin and mainly because of Anglicisms. The political, cultural, social, and economic relationship between the United States of America and Puerto Rico, dating from 1898, has resulted in the inhabitants of the Island changing the lexicon of informal Spanish spoken as a result of the influence of English.

Puerto Ricans are also American citizens and, therefore, can freely enter and leave this northern country. The contact with English that these individuals have when leaving their country allows them to make combinations, adaptations, loans, and other changes to Spanish when they are in informal situations of daily discourse. These changes are generalized and transferred from one generation to another until they manage to position themselves and become part of the Spanish that most Puerto Ricans understand when communicating. Another factor that allows this cultural phenomenon to occur is the lack of full command of English or Spanish at any given time. Given the need to speak fluently in a familiar or trustworthy environment, speakers resort to these tactics to make themselves understood more freely. Another factor of great influence is the dominance of English as a second language in Puerto Rico and in most countries of the world.

Spanish as a fundamental element that identifies Puerto Rican culture, is characterized as a language highly influenced by American English, as can be seen in the anglicisms presented in this study. Although some of them are also part of the Spanish lexicon of other Latin countries, most have been originally created by Puerto Ricans. Examples of these are: rufo, carpeta, suinguiar, norsa, liqueo, pichar, morón, disectar, badtripeao, pichar, yistro, raitrú, mátres, janguear, pai de chery, burrito de bif, dámelo plein, and others. It can also be observed that they do not belong to a single sector but are essentially scattered in the economic, social, and cultural spheres. As stated by Cortés et al. (2005), these interventions lexical to Spanish are already extended to other written media (magazines, newspapers, advertisements, Internet). Consequently, the citizens of Puerto Rico have, and will continue to have, influence with their anglicisms, both on the Island and in the Hispanic population living in the United States of America.

\section{Conclusion}

According to the results obtained in this study, 80 anglicisms were found in the speech of Puerto Ricans. Within the category of original anglicisms there are 43 , in the adapted category there are 30 , in the category 
of hybrids there are five, and only one angled neologism appears in the list. Most of them are original anglicisms, implying that it is easier for speakers to maintain their original form of English with a slight change in pronunciation similar to Spanish. Examples of these are: party, gym, folder, topping, brownie, lobby, brown, break, frappe, and others. In the case of the adapted ones, that occupy the second position, this peculiar and funny way is manifested when one or more segments of the Spanish linguistic structure are changed or added to the English root. Some examples in this category are: rufo, carpeta, yarda, norsa, riversa, and mátres. Meanwhile, hybrids occur much less frequently since they require the combination of words from the two languages (dámelo plein, taco salad, burrito de bif, pai de chery, los yunáis). It can be noted that the hybrid anglicisms found are within the food sector, except los yunáis. Finally, there is only one angled neologism: janguear, which has its derivative jangueo without an English equivalent.

To continue making an empirical, updated, and broader inventory that collects all the anglicisms of Puerto Rico, researchers are advised to use other means to collect the data. In particular, the use of individual interviews and focus groups can be of great importance, as well as case studies. More research is needed to collect and analyze the richness of the so-called Spanglish of which we are all a part in one form or another. Knowing the communication processes is essential to making the human being a more productive entity in any society where he/she decides to live.

\section{References}

Apud Peláez, I. E. (2013). Repensar el método etnográfico. Hacia una etnografía multitécnica reflexiva y abierta al diálogo interdisciplinario. Revista Antípoda, (16), 215-235. doi: 10.7440/antipoda16.2013.10

Chambers, J. K. (2009). Sociolinguistic Theory: Linguistic Variation and its Social Significance. London: Wiley-Blackwell.

Cordero Monge, S. (2007). Consideraciones en torno a la marcación y definición del léxico de especialidad en los diccionarios generales. Káñina, 31(2), 61-72.

Cortés, I., Ramírez J., Rivera, M., Viada, M. y Fayer, J. (2005). Dame un hamburger plain con ketchup y papitas. English Today, 21(2) 35-42. doi: $10.1017 / \mathrm{s} 0266078405002051$

Silva-Corvalán, C. \& Enrique-Arias, A. (2017). Sociolingüística y pragmática del español. Washington D. C.: Georgetown University Press.

Creswell, J. W. (2013). Qualitative inquiry and research design: Choosing among five approaches. Thousand Oaks, CA.: Sage Publications, Inc.

Escobar, A. M. \& Potowski, K. (2015). El español de los Estados Unidos. Cambridge: Cambridge University Press. 
Hsieh, H. \& Shannon, S. (2005). Three Approaches to Qualitative Content Analysis. Qualitative Health Research, 15(9), 1277-1288. doi: 10.1177/1049732305276687

Instituto de Estadísticas de Puerto Rico (2016). Population and Housing Unit Estimates. San Juan de Puerto Rico: United States Census Bureau.

Negrón M., M. (2013). La extensión semántica de estar en la estructura cópula + adjetivo en el español de Puerto Rico. (Master Thesis). Available from ProQuest Dissertations Publishing.

Medina-Rivera, A. (1999). Variación fonológica y estilística en el español de Puerto Rico. Hispania, 82(3) 529-541.

Olivero H., N. (2012). Una descripción del movimiento cuantificador más en las construcciones superlativas de relativo dentro de construcciones copulativas enfáticas del español de San Juan de Puerto Rico. (Master Thesis). Available from ProQuest Dissertations Publishing.

Pérez C., M. (2008). Codes Witching and Identity among Island Puerto Rican Bilinguals. (Doctoral dissertation). Retrieved from https://repository. library.georgetown.edu/bitstream/handle/10822/553245/perezMarisol.p df

Real Academia Española (2017). Definición de anglicismo. Diccionario de la lengua española. Retrieved from http://dle.rae.es/?id=2eG56Yz

Regis, J. A. (1998). Historia de la ciudadanía americana en Puerto Rico. Retrieved from http://www.puertoricousa.com/spanish/history.htm

Rezvani, D. A. (2007). The Basis of Puerto Rico's Constitutional Status: Colony, Compact, or "Federacy"? Political Science Quarterly, 122(1) 115-140.

Rodríguez M., M. (2002). Los anglicismos de frecuencia sintácticos en español: Estudio empírico. Asociación Española de Lingüística Aplicada, 15, 149-170.

Shenk, E. (2012). Puerto Rico's Language Officialization Debates: perspectives from a mountain corridor community. CENTRO: Journal of the Center for Puerto Rican Studies, 24(1), 90-119.

U. S. Census Bureau, 2006-2010. (December, 2011). Native North American languages spoken at home in the United States and Puerto Rico: 20062010. U.S. Department of Commerce Economic and Statistics Administration. Retrieved from http://www.census.gov/prod/2011pubs/ acsbr10-10.pdf

Villanueva F., O. (2009). A Contrastive Analysis of English Influences on the Lexicon of Puerto Rican Spanish and Puerto Rico and St. Croix. (Doctoral dissertation). Universidad de Puerto Rico, Río Piedras.

Wheeler, E. S. (2015). A Framework for Studying Languages in Contact: a Prolegomenon to a Theory. Word, 61(1), 75-86. doi: 10.1080/00437956.2015.1006860 
Mylord Reyes Tosta. International Journal of Educational Excellence (2019) Vol. 5, No. 2, 15-

28. ISSN 2373-5929.

DOI: $10.18562 /$ IJEE.046

C 2019 Reyes Tosta; licensee International Journal of Educactional Excellence, Universidad Ana G. Méndez (UAGM). This is an Open Access article distributed under the terms of the Creative Commons Attribution License (http://creativecommons.org/licenses/by/4.0), which permits unrestricted use, distribution, and reproduction in any medium, provided the original work is properly credited. 